\title{
Synthesis and Evaluation of Baylis-Hillman Reaction Derived Imidazole and Triazole Cinnamates as Antifungal Agents
}

\author{
Grady L. Nelson, ${ }^{1}$ Michael J. Williams, ${ }^{2}$ Shirisha Jonnalagadda, ${ }^{1}$ Mohammad A. Alam, \\ Gautam Mereddy, ${ }^{2}$ Joseph L. Johnson, ${ }^{2}$ and Sravan K. Jonnalagadda $\left(^{1}\right.$ \\ ${ }^{1}$ Integrated Biosciences Graduate Program, University of Minnesota, Duluth, MN 55805, USA \\ ${ }^{2}$ Department of Chemistry and Biochemistry, University of Minnesota, Duluth, MN 55805, USA \\ Correspondence should be addressed to Sravan K. Jonnalagadda; skjonnal@d.umn.edu
}

Received 21 May 2018; Revised 15 September 2018; Accepted 24 September 2018; Published 16 October 2018

Academic Editor: Benedetto Natalini

Copyright (C) 2018 Grady L. Nelson et al. This is an open access article distributed under the Creative Commons Attribution License, which permits unrestricted use, distribution, and reproduction in any medium, provided the original work is properly cited.

Allylic acetates derived from Baylis-Hillman reaction undergo efficient nucleophilic isomerization with imidazoles and triazoles to provide imidazolylmethyl and triazolylmethyl cinnamates stereoselectively. Antifungal evaluation of these derivatives against Cryptococcus neoformans exhibits good minimum inhibitory concentration values. These compounds exhibit low toxicity in proliferating MCF-7 breast cancer cell line. Structure activity relationship studies indicate that halogenated aromatic derivatives provide better antifungal activity.

\section{Introduction}

Due to the advances in modern medicine, overall life expectancy is being greatly extended; however the unintended consequence is a large increase in reduced immune system and immunocompromised cancer and organ transplant patients. This extension of life expectancy resulted in a lot of opportunistic fungal and bacterial infections often leading to patient mortality. Imidazole and triazole based antifungal agents have been the mainstay of the treatments for fungal infections (Figure 1) [1-4]. With the advent of resistance to many of the clinically used drugs, novel candidate compounds that can overcome the resistance are urgently required. In this regard, we envisioned to develop novel imidazole and triazole based small molecules that could be easily synthesized and densely functionalized for structure activity relationship studies.

Cryptococcus neoformans consists of three variants: $C$. neoformans var. grubii, C. neoformans var. neoformans, and C. neoformans var. gattii. The variants grubii and gattii are mainly responsible for most cases of pathogenic infections in both immunocompromised and sometimes even immunocompetent patients [5-11]. Without a proper treatment, this infection will invariantly lead to patient morbidity and mortality. The standard treatment includes amphotericin-B infusion in combination with 5-flucytosine to reduce the fungal infection followed by maintenance therapy with azoles such as fluconazole. Literature reports indicate that Cryptococcus neoformans is sensitive to fluconazole [5-11]. In many developing and poor countries, the usage of amphotericin-B and 5-flucytosine adds a lot of cost burden and treatment may be mainly limited to high-dose azoles. These drugs have many side effects such as hepatotoxicity and myelosuppression [9]. However, resistance to azole based therapy has been detected in some Cryptococcus based infections [8] and hence development of novel and inexpensive azole based therapeutics will be highly beneficial for the treatment of Cryptococcus and other fungal based infections.

The Baylis-Hillman (BH) reaction is an important carbon-carbon bond forming synthetic transformation that provides highly substituted allylic alcohols and amines in one step [12-16]. Nucleophilic substitution on the BH derived allylic alcohols can be carried out through the conversion of the alcohol unit to the bromide or acetate leaving groups (Figure 2). BH reaction template also offers high tunability at three different places. This reaction has been extensively investigated for various types of pharmaceutical development [17-24]. 


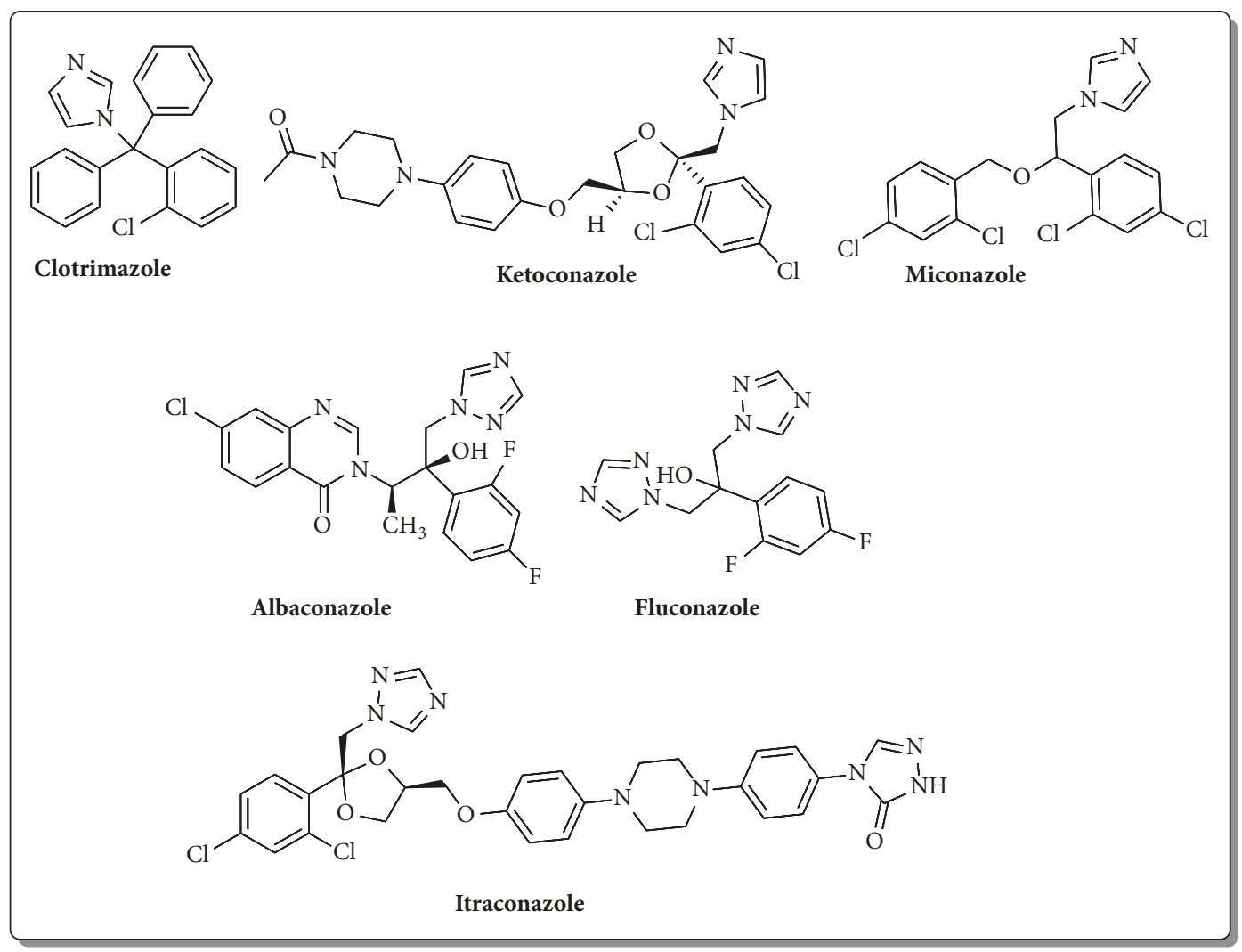

Figure 1: Few examples of imidazole and triazole based antifungal agents.
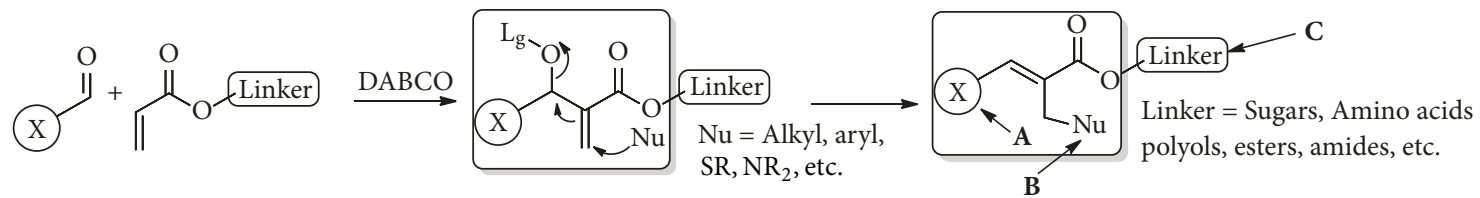

FIgURE 2: Baylis-Hillman reaction template.

The isomerization of $\mathrm{BH}$ acetates or bromides with imidazole or triazoles provides facile access to functionalized allyl imidazoles or allyl triazoles [25-29]. This protocol allows high flexibility and rapid access to structurally diverse functionalized allyl imidazoles and triazoles. If these molecules exhibit any antifungal activity, a new class of imidazole and triazole based antifungal agents will be constituted. With these goals in mind, we undertook a project on the development of novel functionalized imidazoles and triazoles utilizing $\mathrm{BH}$ chemistry and our results are reported below.

\section{Materials and Methods}

\subsection{Representative Procedure for Isomerization of Baylis-Hillman (BH) Acetates}

2.1.1. Synthesis of Methyl (E)-2-((1H-imidazol-1-yl)methyl)-3(4-chlorophenyl)acrylate (12). To a stirred solution of $\mathrm{BH}$ acetate $(5 \mathrm{mmol})$ in 1:1 THF-water $(10 \mathrm{~mL})$ was added imidazole $(7.5 \mathrm{mmol})$ at room temperature and stirred overnight.
The reaction mixture was extracted three times with ethyl acetate-water and the combined organic layers were dried using $\mathrm{MgSO}_{4}$. The dried organic layer was concentrated in vacuum and purified via silica gel column chromatography to obtain the pure methyl (E)-2-((1H-imidazol-1-yl)methyl)-3(4-chlorophenyl)acrylate 12 in $63 \%$ yield. ${ }^{1} \mathrm{H}$ NMR $(500 \mathrm{MHz}$, $\left.\mathrm{CDCl}_{3}\right) \delta 7.96(\mathrm{~s}, 1 \mathrm{H}), 7.45(\mathrm{~s}, 1 \mathrm{H}), 7.39(\mathrm{~d}, J=8 \mathrm{~Hz}, 2 \mathrm{H}), 7.24$ $(\mathrm{d}, J=8 \mathrm{~Hz}, 2 \mathrm{H}), 7.01(\mathrm{~s}, 1 \mathrm{H}), 6.84(\mathrm{~s}, 1 \mathrm{H}), 4.94(\mathrm{~s}, 2 \mathrm{H})$, $3.80(\mathrm{~s}, 3 \mathrm{H}) \mathrm{ppm} ;{ }^{13} \mathrm{C} \mathrm{NMR}\left(125 \mathrm{MHz} \mathrm{CDCl}_{3}\right) \delta 166.9,143.7$, $137.2,136.1,132.5,130.4,129.6,127.8,118.9,52.8,43.1 \mathrm{ppm}$. Anal. Calcd for $\mathrm{C}_{14} \mathrm{H}_{13} \mathrm{ClN}_{2} \mathrm{O}_{2}$ (276.72): C 60.77, $\mathrm{H}$ 4.74, N 10.12 Found: C 60.47, H 4.71, N 9.93.

2.1.2. Synthesis of Methyl (E)-2-((1H-1,2,4-triazol-1-yl)methyl)3-(4-fluorophenyl)acrylate (24). The same procedure was followed and imidazole was replaced with 1,2,4-triazole. Compound 24 yield: $55 \%$; ${ }^{1} \mathrm{H}$ NMR (500 $\left.\mathrm{MHz}, \mathrm{CDCl}_{3}\right) \delta$ 8.28 (s, $1 \mathrm{H}), 8.03$ (s, $1 \mathrm{H}), 7.98$ (s, $1 \mathrm{H}), 7.80-7.78(\mathrm{~m}, 2 \mathrm{H})$, $7.17(\mathrm{t}, J=8.25 \mathrm{~Hz}, 2 \mathrm{H}), 5.19(\mathrm{~s}, 2 \mathrm{H}), 3.83$ (s, $3 \mathrm{H})$ ppm; ${ }^{13} \mathrm{C}$ NMR $(125 \mathrm{MHz}, \mathrm{CDCl} 3) \delta 167.1,164.8,162.8,152.1,144.5$, 


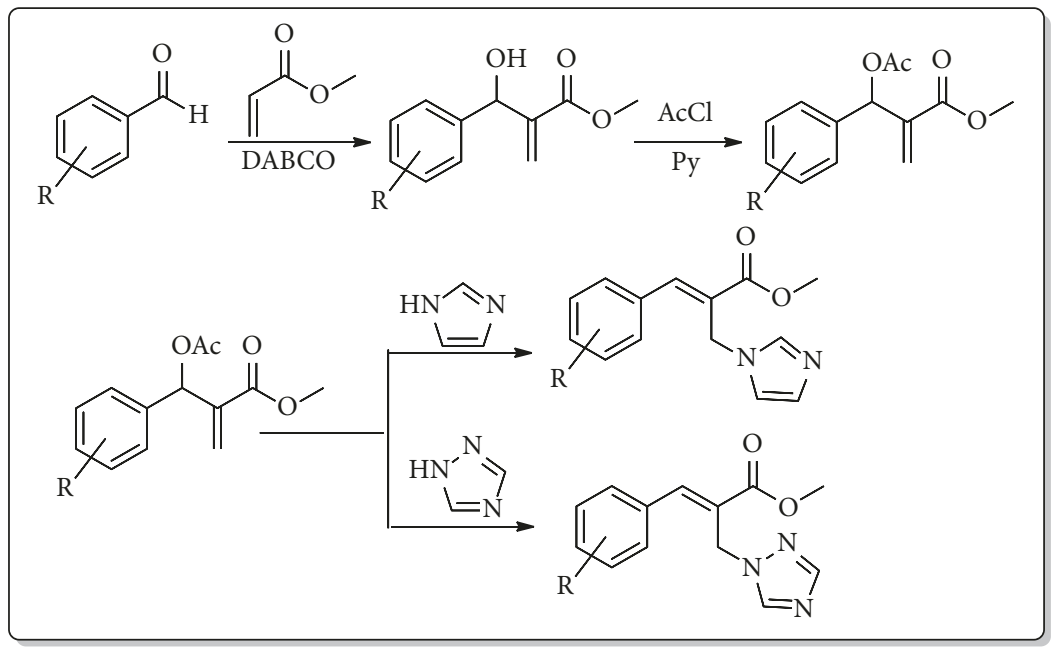

SCHEME 1: Synthesis of 2-(imidazolylmethyl) and 2-(triazolylmethyl) cinnamates.

132.1, 130.1, 125.2, 116.4, 116.3, 52.8, 46.2 ppm; Anal. Calcd for $\mathrm{C}_{13} \mathrm{H}_{12} \mathrm{FN}_{3} \mathrm{O}_{2}$ (261.26): C 59.77, $\mathrm{H}$ 4.63, N 16.08 Found: C 59.96, H 4.69, N 16.00.

2.2. Disk Diffusion Susceptibility Testing. Kirby-Bauer testing was used as the initial screen for determining the antifungal activity of the compounds. Cryptococcus neoformans was obtained from the ATCC (ATCC 32045). Isolates were cultured in phenol red free RPMI medium supplemented with $3 \%$ glucose (modified as indicated in the CLSI protocol M27A3). The culture was grown up to an OD (0.4-0.5) at $530 \mathrm{~nm}$ giving an inoculum stock of $1 \times 10^{6}$ to $5 \times 10^{6}$ cells per $\mathrm{mL}$. Sterile swabs were used to spread the inoculum evenly on LB agar plates containing ampicillin. $5 \mu \mathrm{L}$ of each $100 \mathrm{mM}$ DMSO stock solution was added to sterile $1 \mathrm{~cm}$ diameter Whatman filter discs and then placed into a quadrant of a freshly streaked plate. The zone of inhibition was measured after 24 and 48 hours. Each compound was tested in at least triplicate, and fluconazole was used as a positive control.

2.3. Minimum Inhibitory Concentration (MIC) Assay. MIC assays were performed on samples that showed zones of inhibition greater than $1.5 \mathrm{~cm}$. A fresh stock inoculum was diluted 1000-fold in modified RPMI medium. Each 28 $\mathrm{mg} / \mathrm{mL} \mathrm{mM}$ DMSO stock solution was diluted to $56 \mu \mathrm{g} / \mathrm{mL}$. $100 \mu \mathrm{L}$ of the diluted C. neoformans inoculum was added to each well of a round-bottom 96-well plate containing twofold serial dilutions of each stock antifungal compound solution beginning at $28 \mu \mathrm{g} / \mathrm{mL}$ with a DMSO-only control in the final well of each row. The plates were incubated at $37^{\circ} \mathrm{C}$ in a non$\mathrm{CO}_{2}$ incubator, and the absorbance at $600 \mathrm{~nm}$ was measured using a plate reader after 24 and 48 hours. The reported MICs corresponded to the lowest compound dilution that significantly inhibited growth (more than 50\% relative to control). Each compound was tested in at least triplicate, and fluconazole and miconazole were used as positive controls, returning MIC values consistent with published data.
2.4. Sulforhodamine-B Cytotoxicity Assay. A standard sulforhodamine-B assay $[30,31]$ was used to evaluate the cytotoxicity of the synthesized compounds on proliferating cancer cells. MCF-7 cells were cultured in $5 \% \mathrm{CO}_{2}$ atmosphere at $37^{\circ} \mathrm{C}$ in Iscove's Modified Dulbecco's medium containing $10 \%$ FBS and $1 \%$ antibiotic (penicillinstreptomycin). MCF-7 cells were seeded at a concentration of approximately $5 \times 10^{5}$ cells $/ \mathrm{mL}$ in 48 well plates such that each well contains $400 \mu \mathrm{L}$ of media and incubated for 24 hours. The test compounds were initially diluted in DMSO and diluted 1000 times in growth media so that the final DMSO concentration was $<0.1 \%$. Growth media were removed from 48 well plates and test compounds in $400 \mu \mathrm{L}$ of growth media were added to the wells. Paclitaxel, DMSO, and growth media were used as controls. The plates were incubated for 72 hours. After removing the media, the cells were washed with $1 \%$ Dulbecco's phosphate-buffered saline and dried. $100 \mu \mathrm{L}$ of $0.5 \%$ sulforhodamine-B (SRB) in $1 \%$ acetic acid was added in each well and incubated at $37^{\circ} \mathrm{C}$ for 45 minutes. SRB solution was removed and the wells were washed 5 times with $1 \%$ acetic acid solution and dried. The cells were dissolved in $400 \mu \mathrm{L}$ of $10 \mathrm{mM}$ Tris base $(\mathrm{pH} 10.2)$ and absorbance was recorded at $540 \mathrm{~nm}$. The absorbance is directly proportional to the cellular protein.

\section{Results and Discussion}

We initiated the synthesis of $\mathrm{BH}$ derived allyl alcohols with various aromatic aldehydes with methyl acrylate in the presence of DABCO. The reactions took place smoothly in all these cases and the product alcohols were obtained in good yields upon silica gel column chromatography (70-85\%). These alcohols were converted into acetates by treatment with acetyl chloride in the presence of triethylamine or pyridine. Reaction of these acetates with imidazole/triazole in THF and water at room temperature led to the formation of corresponding cinnamoyl imidazoles/triazoles 126 (Scheme 1, Table 1). The compounds were characterized 
TABLE 1: 2-(imidazolylmethyl) and 2-(triazolylmethyl) cinnamates.

Compound Number

1

2

3

5

6

8

9

10

11

$$
\text { Compound }
$$<smiles>CCOC(=O)/C(=C/c1ccccc1)Cn1ccnc1</smiles><smiles>COC(=O)/C(=C/c1cccc2ccccc12)Cn1ccnc1</smiles><smiles>COC(=O)/C(=C/c1ccc(C)cc1)Cn1ccnc1</smiles><smiles>COC(=O)/C(=C/c1ccc(OC)cc1)Cn1ccnc1</smiles><smiles>COC(=O)/C(=C/c1cc(OC)c(OC)c(OC)c1)Cn1ccnc1</smiles><smiles>COC(=O)/C(=C/c1ccc([N+](=O)[O-])cc1)Cn1ccnc1</smiles><smiles>COC(=O)/C(=C/c1cccc([N+](=O)[O-])c1)Cn1ccnc1</smiles><smiles>COC(=O)/C(=C/c1ccccc1[N+](=O)[O-])Cn1ccnc1</smiles><smiles>COC(=O)/C(=C/c1ccc(C#N)cc1)Cn1ccnc1</smiles><smiles>COC(=O)/C(=C/c1cccc(C#N)c1)Cn1ccnc1</smiles><smiles>COC(=O)/C(=C/c1ccc(F)cc1)Cn1ccnc1</smiles>

$\%$ yield 
TABle 1: Continued.

Compound Number

12<smiles>COC(=O)/C(=C/c1ccc(Cl)cc1)Cn1ccnc1</smiles>

13<smiles>COC(=O)/C(=C/c1ccc(Br)cc1)Cn1ccnc1</smiles>

14<smiles>COC(=O)/C(=C/c1ccccc1)Cn1cncn1</smiles><smiles>COC(=O)/C(=C/c1cccc2ccccc12)Cn1cncn1</smiles><smiles>COC(=O)/C(=C/c1ccc(C)cc1)Cn1cncn1</smiles><smiles>COC(=O)/C(=C/c1ccc(OC)cc1)Cn1cncn1</smiles><smiles>COC(=O)/C(=C/c1cc(OC)c(OC)c(OC)c1)Cn1cncn1</smiles><smiles>COC(=O)/C(=C/c1ccc([N+](=O)[O-])cc1)Cn1ccnc1</smiles><smiles>COC(=O)/C(=C/c1cccc([N+](=O)[O-])c1)Cn1cncn1</smiles><smiles>COC(=O)/C(=C/c1ccccc1[N+](=O)[O-])Cn1cncn1</smiles> 
TABle 1: Continued.

Compound Number

by proton and carbon NMR spectroscopy (Supplementary Materials (available here)). In all the cases, the E-isomer of the imidazole/triazole olefins was predominantly obtained (>95\%) based on crude NMR analysis.

\section{Biological Evaluation}

After synthesizing $\mathrm{BH}$ derived functionalized imidazoles and triazoles, we then evaluated the antifungal efficacy of all these derivatives on a representative fungal species Cryptococcus neoformans. Initial antifungal activities were carried out using Kirby-Bauer disk method. This method is rapid and provides qualitative information about the biological activity of the molecules. Gratifyingly, many of the derivatives were found to be active with good to moderate zone of inhibition values $(1-3.7 \mathrm{~cm})$. The halo of $1 \mathrm{~cm}$ means that there was no inhibition. The top five compounds $(2,11,12,13$, and 24$)$ that exhibited highest zone of inhibition were further evaluated for minimum inhibitory concentration (MIC) values. The most active compounds were tested in at least triplicate using a 96-well plate in serial dilutions. Fluconazole and miconazole were used as positive controls, returning MIC values consistent with published data. Some of the tested compounds exhibited good activity against Cryptococcus neoformans $(\sim 8-13 \mu \mathrm{g} / \mathrm{mL}$, Table 2).

We then evaluated for the cytotoxicity of these compounds using a breast cancer cell line MCF-7. Sulforhodamine- $B$ assay was used to determine the cytotoxicity profile of these compounds. All the compounds were tested in triplicate in 48-well plates. None of the compounds were toxic below $50 \mu \mathrm{M}$ concentration in proliferating cells indicating the utility of these imidazole and triazole derivatives for further development.

\section{Conclusions}

In conclusion, we synthesized several imidazoles and triazoles containing small molecules derived from $\mathrm{BH}$ reaction template. The synthesized molecules including the starting materials were evaluated for their antifungal activity against C. neoformans. Several halogenated aromatic imidazole and triazole derivatives exhibited promising antifungal activity against $C$. neoformans. It is also encouraging to note that the active molecules exhibited little to no cytotoxicity when tested on proliferating breast cancer cell line MCF-7. The compounds are easy to synthesize and exhibit selective antifungal activity against C. neoformans. We believe that this work should attract the attention of medical and pharmaceutical scientists for further structure activity investigation and development of more potent analogs for clinical use.

\section{Data Availability}

An experimental procedure describing the synthesis of compounds, along with data with critical compounds, has been provided in the manuscript for others to utilize for their research.

\section{Conflicts of Interest}

The authors declare that there are no conflicts of interest regarding the publication of this paper.

\section{Acknowledgments}

The authors acknowledge Department of Chemistry and Biochemistry University of Minnesota Duluth for funding and providing facilities. 
TABLe 2: Minimum inhibitory concentrations (MIC50*) of lead molecules in $\mu \mathrm{g} / \mathrm{mL}$.

\begin{tabular}{|c|c|c|}
\hline Compound Number & Compound & Cryptococcus neoformans \\
\hline 2 & & $8 \pm 4$ \\
\hline 11 & & $11 \pm 4$ \\
\hline 12 & & $9 \pm 4$ \\
\hline 13 & & $9 \pm 4$ \\
\hline \multirow[t]{3}{*}{24} & & $13 \pm 5$ \\
\hline & Fluconazole & $3 \pm 1$ \\
\hline & Miconazole & $<0.5$ \\
\hline
\end{tabular}

* Average \pm SEM of three separate experiments.

\section{Supplementary Materials}

NMR spectroscopic data and elemental analysis of all the synthesized compounds are included in the Supplementary Materials. (Supplementary Materials)

\section{References}

[1] A. S. Suvarna, "Imidazole and its derivatives and importance in the synthesis of pharmaceuticals: a review," Research Journal of Chemical Sciences, vol. 5, no. 10, pp. 67-72, 2015.

[2] L. Zhang, X. M. Peng, G. L. V. Damu, R. X. Geng, and C. H. Zhou, "Comprehensive review in current developments of imidazole-based medicinal chemistry," Medicinal Research Reviews, vol. 34, no. 2, pp. 340-437, 2014.

[3] R. J. Bhor, C. J. Bhangale, and V. D. Wagh, "A review on "Drugs containing imidazoles and triazole heterocyclic ring in antifungal therapy", International Journal of Pharmacy and Technology, vol. 8, no. 3, pp. 4521-4544, 2016.

[4] H.-Z. Zhang, L.-L. Gan, H. Wang, and C.-H. Zhou, "New progress in azole compounds as antimicrobial agents," MiniReviews in Medicinal Chemistry, vol. 17, no. 2, pp. 122-166, 2017.

[5] L. Rossato, É. S. Loreto, T. P. Venturini et al., "In vitro interaction of antifungal and antibacterial drugs against Cryptococcus neoformans var. grubii before and after capsular induction," Medical Mycology, vol. 53, no. 8, pp. 885-889, 2015.

[6] X. Fan, M. Xiao, S. Chen et al., "Predominance of Cryptococcus neoformans var. grubii multilocus sequence type 5 and emergence of isolates with non-wild-type minimum inhibitory concentrations to fluconazole: a multi-centre study in China," Clinical Microbiology and Infection, vol. 22, no. 10, pp. 887.el887.e9, 2016.

[7] E. Nascimento, L. H. Vitali, M. R. V. Z. Kress, and R. Martinez, "Cryptococcus neoformans and C. Gattii isolates from both HIV-infected and uninfected patients: Antifungal susceptibility and outcome of cryptococcal disease," Revista do Instituto de Medicina Tropical de São Paulo, vol. 59, article no. e49, 2017.

[8] E. Sionov, Y. C. Chang, H. M. Garraffo, and K. J. Kwon-Chung, "Heteroresistance to fluconazole in Cryptococcus neoformans is intrinsic and associated with virulence," Antimicrobial Agents and Chemotherapy, vol. 53, no. 7, pp. 2804-2815, 2009.

[9] K. Datta, N. Jain, S. Sethi, A. Rattan, A. Casadevall, and U. Banerjee, "Fluconazole and itraconazole susceptibility of clinical isolates of Cryptococcus neoformans at a tertiary care centre in India: A need for care," Journal of Antimicrobial Chemotherapy, vol. 52, no. 4, pp. 683-686, 2003.

[10] A. Mourad and J. Perfect, "Present and Future Therapy of Cryptococcus Infections," Journal of Fungi, vol. 4, no. 3, p. 79, 2018.

[11] R. K. Pettit, K. K. Repp, and K. C. Hazen, "Temperature affects the susceptibility of Cryptococcus neoformans biofilms to antifungal agents," Medical Mycology, vol. 48, no. 2, pp. 421-426, 2010 .

[12] K. C. Bharadwaj, "Intramolecular Morita-Baylis-Hillman and Rauhut-Currier reactions. A catalytic and atom economic route 
for carbocycles and heterocycles," RSC Advances, vol. 5, no. 93, pp. 75923-75946, 2015.

[13] Y. Wei and M. Shi, "The Morita-Baylis-Hillman (MBH) and Hetero-MBH Reactions," Comprehensive Enantioselective Organocatalysis: Catalysts, Reactions, and Applications, vol. 3-3, pp. 899-939, 2013.

[14] Y. Wei and M. Shi, "Recent advances in organocatalytic asymmetric morita-baylis-hillman/aza- morita-baylis-hillman reactions," Chemical Reviews, vol. 113, no. 8, pp. 6659-6690, 2013.

[15] H. Sasai and S. Takizawa, 6.9 C-C Bond Formation: (aza) Morita-Baylis-Hillman Reaction Comprehensive Chirality, vol. 6, 2012.

[16] D. Basavaiah and G. Veeraraghavaiah, "The Baylis-Hillman reaction: A novel concept for creativity in chemistry," Chemical Society Reviews, vol. 41, no. 1, pp. 68-78, 2012.

[17] W. A. V. da Silva, D. C. Rodrigues, R. G. de Oliveira et al., "Synthesis and activity of novel homodimers of MoritaBaylis-Hillman adducts against Leishmania donovani: A twin drug approach," Bioorganic \& Medicinal Chemistry Letters, vol. 26, no. 18, pp. 4523-4526, 2016.

[18] W. Hou, Z.-Y. Wang, C.-K. Peng et al., "Novel securinine derivatives as topoisomerase I based antitumor agents," European Journal of Medicinal Chemistry, vol. 122, pp. 149-163, 2016.

[19] M. H. Manyeruke, T. O. Olomola, S. Majumder et al., "Synthesis and evaluation of 3-hydroxy-3-phenylpropanoate ester-AZT conjugates as potential dual-action HIV-1 Integrase and Reverse Transcriptase inhibitors," Bioorganic \& Medicinal Chemistry, vol. 23, no. 24, pp. 7521-7528, 2015.

[20] T. Kumar, D. Verma, R. F. S. Menna-Barreto, W. O. Valença, E. N. Da Silva Júnior, and I. N. N. Namboothiri, "Synthesis of imidazoles via cascade reaction of nitroallylic acetates with amidines and studies on their trypanocidal activity," Organic \& Biomolecular Chemistry, vol. 13, no. 7, pp. 1996-2000, 2015.

[21] S. Bhowmik and S. Batra, "Applications of morita-baylishillman reaction to the synthesis of natural products and drug molecules," Current Organic Chemistry, vol. 18, no. 24, pp. 30783119, 2014.

[22] S. Kłossowski, A. Muchowicz, M. Firczuk et al., "Studies toward novel peptidomimetic inhibitors of thioredoxin-thioredoxin reductase system," Journal of Medicinal Chemistry, vol. 55, no. 1, pp. 55-67, 2012.

[23] C. G. Lima-Junior and M. L. A. A. Vasconcellos, "MoritaBaylis-Hillman adducts: Biological activities and potentialities to the discovery of new cheaper drugs," Bioorganic \& Medicinal Chemistry, vol. 20, no. 13, pp. 3954-3971, 2012.

[24] L. N. Solano, G. L. Nelson, C. T. Ronayne et al., "Synthesis, in vitro, and in vivo evaluation of novel functionalized quaternary ammonium curcuminoids as potential anti-cancer agents," Bioorganic \& Medicinal Chemistry Letters, vol. 25, no. 24, pp. 5777-5780, 2015.

[25] A. Köseceli Özenç, I. Çelik, and Ş. Kökten, "Stereoselective and regioselective synthesis of $\mathrm{N}$-substituted methyl 2((azolyl)methyl)-3-arylacrylates from Baylis-Hillman acetates," Turkish Journal of Chemistry, vol. 41, no. 3, pp. 323-334, 2017.

[26] M. T. Rodrigues Jr., M. S. Santos, H. Santos, and F. Coelho, "1,1/Carbonyldiimidazole mediates the synthesis of N-substituted imidazole derivatives from Morita-Baylis-Hillman adducts," Tetrahedron Letters, vol. 55, no. 1, pp. 180-183, 2014.

[27] D. Ye, J. Li, C. Li, and X. Jia, "Facile syntheses of N-substituted imidazoles and benzotriazoles from Baylis-Hillman bromides," Chinese Journal of Chemistry, vol. 27, no. 6, pp. 1159-1162, 2009.
[28] J. Li, X. Wang, and Y. Zhang, "Remarkable rate acceleration of water-promoted nucleophilic substitution of Baylis-Hillman acetate: A facile and highly efficient synthesis of $\mathrm{N}$-substituted imidazole," Tetrahedron Letters, vol. 46, no. 31, pp. 5233-5237, 2005.

[29] W. Zhong, Y. Zhao, B. Guo, P. Wu, and W. Su, "Dramatically accelerated addition under solvent-free conditions: An efficient synthesis of (E)-1,2,4-triazole-substituted alkenes from BaylisHillman acetates," Synthetic Communications, vol. 38, no. 19, pp. 3291-3302, 2008.

[30] E. Orellana and A. Kasinski, "Sulforhodamine B (SRB) Assay in Cell Culture to Investigate Cell Proliferation," Bio-protocol, vol. 6, no. 21, p. e1984, 2016.

[31] C. T. Ronayne, L. N. Solano, G. L. Nelson et al., "Synthesis and biological evaluation of 2-alkoxycarbonylallyl esters as potential anticancer agents," Bioorganic \& Medicinal Chemistry Letters, vol. 27 , no. 4 , pp. $776-780,2017$. 

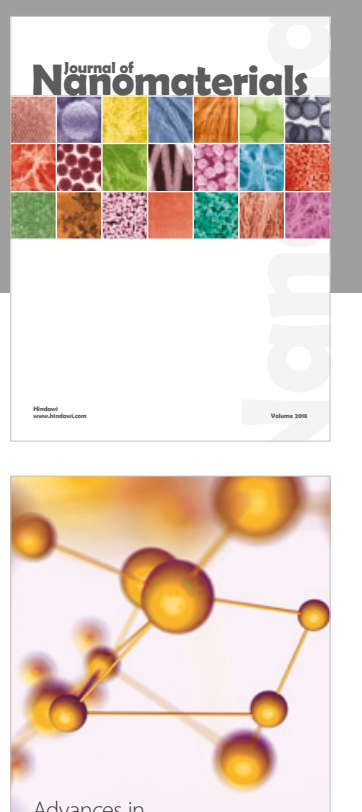

Physical Chemistry
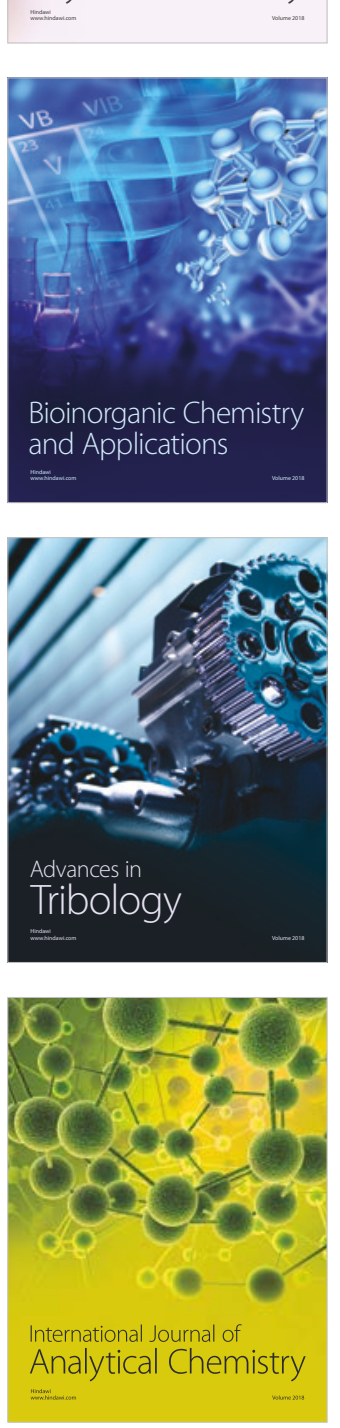

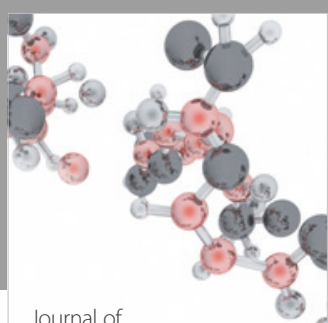

Analytical Methods

in Chemistry

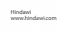

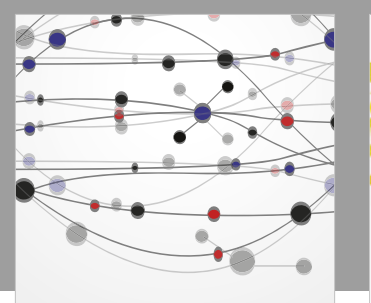

The Scientific World Journal

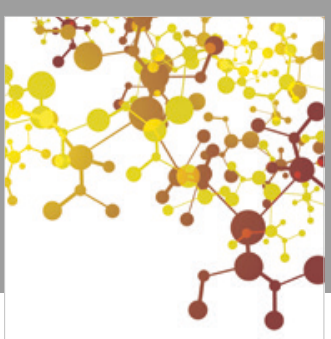

Journal of

Applied Chemistry
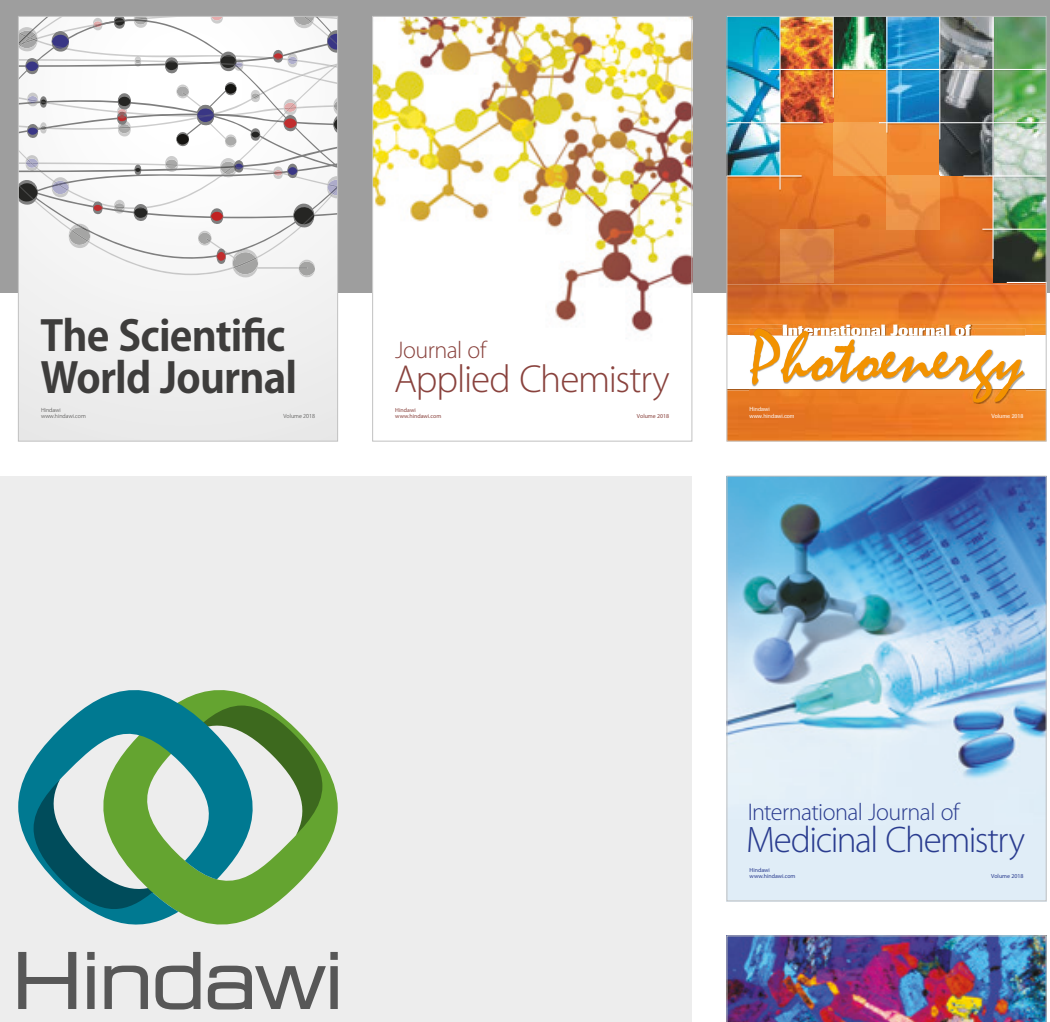

Submit your manuscripts at

www.hindawi.com
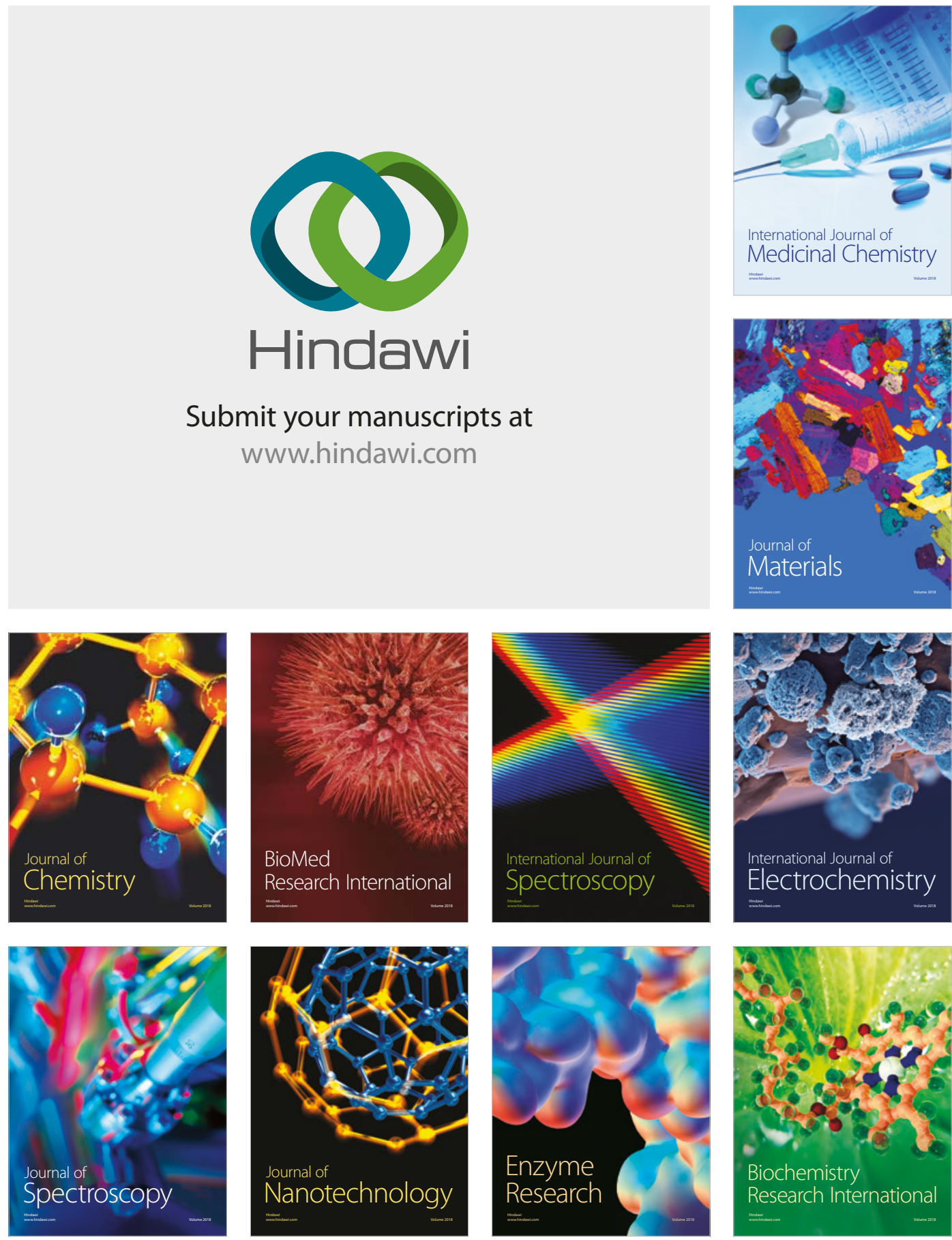
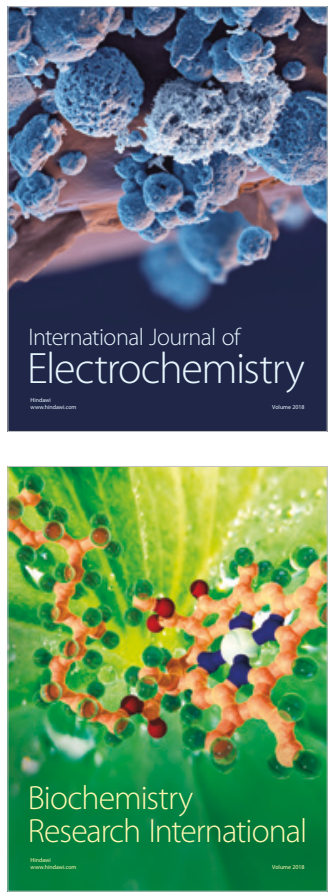